\title{
LPAI - Laboratório de Pesquisa em Ambientes Interativos
}

\author{
Romero Tori, Fábio Roberto de Miranda, Isaura da Cunha Seppi, Daniela Kutschat Hanns, Polise De Marchi \\ Centro Universitário Senac - Campus Santo Amaro \\ Av Engenheiro Eusébio Stevaux, 823 \\ Santo Amaro - São Paulo - SP \\ CEP 04696-000 \\ Email: \{romero.tori, fabio.rmiranda, isaura.cseppi, daniela.khanns, polise.mmarchi, ffoglian\}@sp.senac.br
}

\begin{abstract}
This article presents the LPAI laboratory (Interactive Environments Research Laboratory), which is linked to the Board of Graduate Studies and Research of the Centro Universitário Senac de São Paulo. After a brief history and objectives of the laboratory, its research lines and some of its main projects are presented.
\end{abstract}

Index Terms-Interactive environments, augmented reality, 3D interfaces, interaction design

\section{INTRODUCTION}

LPAI (Interactive Environments Research Laboratory), which is linked to the Board of Graduate Studies and Research of the Centro Universitário Senac de São Paulo, was created in 2005 and aims to develop applied multidisciplinary research related to new forms of interaction, either tangible or intangible, in spaces that may be physical, virtual or mixed. The laboratory gathers professors and students from several fields such as computer science, design, arts and communication, developing research or undergraduate research projects that are sponsored by the Board of Graduate Studies and Research or by public research fostering agencies.

This laboratory succeeded previous research groups that existed since the late 1990s at Senac colleges in computing and in communication \& arts, which were incorporated by the Centro Universitário Senac. Such groups were investigating topics such as games, computer graphics, computer vision, interaction design and ubiquitous computing. Some former researchers of these groups got together and created the LPAI.

LPAI has a dedicated space in Senac Campus at Santo Amaro, São Paulo, that can be adapted for interactive installations or the setup of interactive experiments, and is equipped with projectors, micro-projectors, tablets, motion sensors, 3D monitors, Heliodisplay (vapour projection surface) and digital whiteboard, among other resources. The lab is also equipped with wireless networks and last generation quad core workstations with modern graphics cards. The university campus also provides a shared infra structure available to lab members that includes professional TV studios, digital video editing isles, audio studios, usability tests laboratory, large touch screens panels, devices supporting tabletop interaction, video game rooms and machinery workshops.

\section{RESEARCH LINES}

Projects in LPAI are related to two multidisciplinary research lines: 3D Interaction Design and New Interactive Media.

\section{A. 3D Interaction Design}

This research line studies new interaction paradigms based on the three-dimensionality and its impacts on interface design, user performance and their application for solution of problems in fields such as education and medical systems.

\section{B. New Interactive Media}

This research line focuses on creating new knowledge in communicative processes related to interactive technologies and design, as well as the development of new innovative concepts and artifacts in interactive media, specially with applications in art, education and culture.

\section{Current Projects}

A. Holoface : The Holographic paradigm in Interaction Design and Information Technology

At some point three-dimensional interactions will predominate in user interfaces of digital systems, as has already occurred when the alphanumeric paradigm got supplanted by graphical interfaces, bringing profound impact on how we think and do interaction and information design. The expected emergence of truly holographic displays will further broaden the potential of three-dimensional interactions by increasing the realism and the possibility of direct manipulation of projected objects. This research proposes a new interface concept, based on interaction with holographic images, with the aim of producing innovations in the design of direct manipulation of three-dimensional interactions. For practical experiments the holographic interface will be simulated by means of stereoscopic images and special projection equipment which produces holographic effects, such as Heliodisplay. The recognition of gestures will be made by means of computer vision and/or augmented reality fiducial markers. This project also studies the use of eye tracking as possible facilitators of the process of holographic interaction. Current research products under development include an interactive environment for the visualization of anatomical structures and a reader of books in 
3D. This project suceeds previous published projects that dealt with interaction design [1]-[6], visualization and augmented reality [7]-[9].

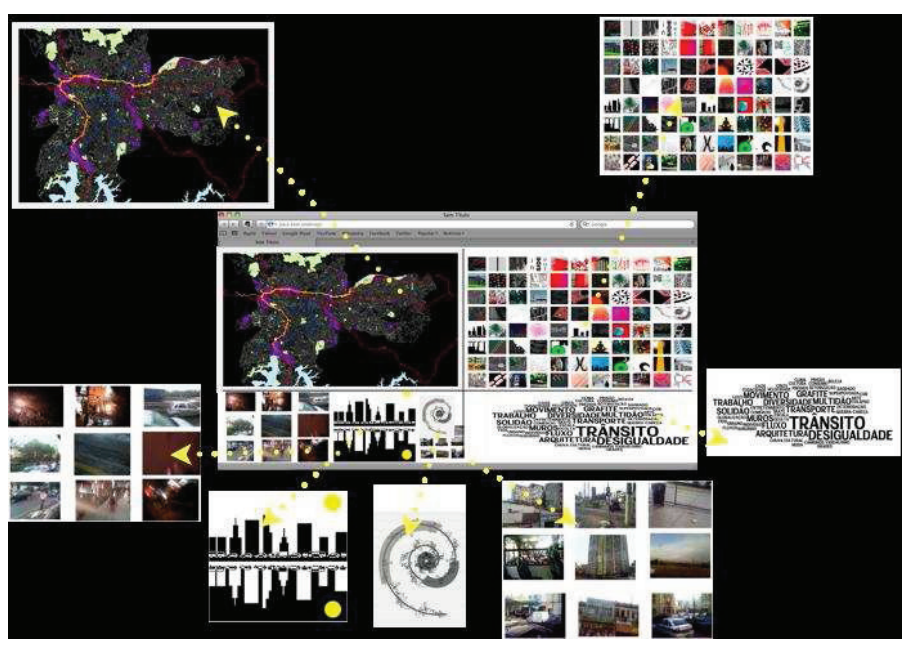

Fig. 1. Interactive and collaborative map of São Paulo

\section{B. Computational Photography: language and interaction}

This is an ongoing project that aims to establish a new scenario to the new practices of photography. New scenarios require new concepts that can extend issues or even subvert well established foundations. This conceptual rearrangement follows mainly as a consequence of the emergence of new digital technologies and the growing number of new software tools to manipulate and construct digital images. Computational Photography is a new emerging field in photography that offers new possibilities for interaction and narrativity that allow the expansion of the its concept, from just still images to include moving images and the possibilities of high resolution. The limits of conceptual photography, in this new context, comprehend those of video and the cinema.

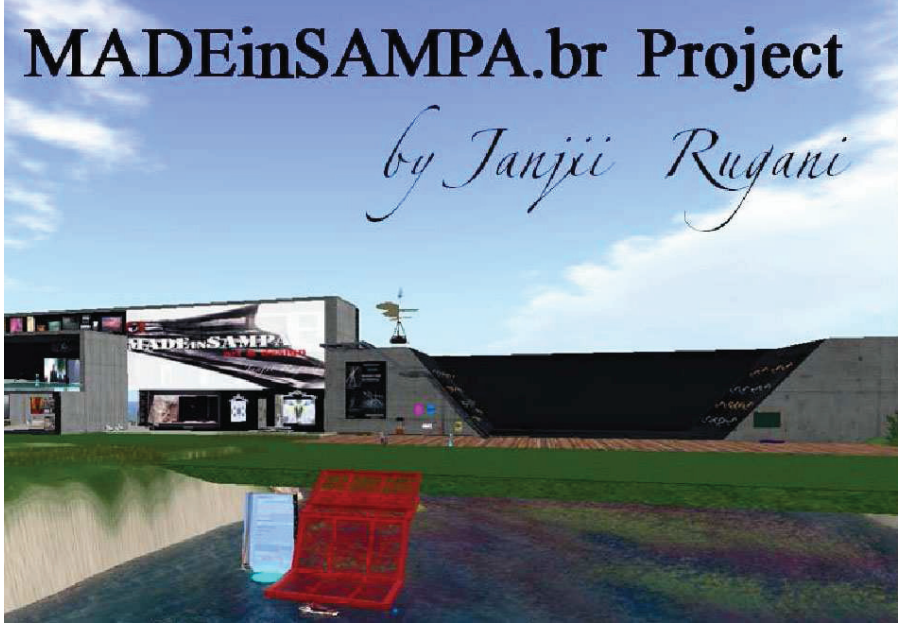

Fig. 2. MADEinSAMPA.br Project at Second Life metaverse
C. Art and Design in Second Life: spaces of production and three-dimensional virtual learningenvironments

This project originated from inquiries and experimentations in computer science, Internet and virtual reality focused on education of art and design over the last seven years [10][12].

One of the goals of this project is to advance the inquiries and systematize the knowledge that was consctructed over its duration related to teaching and learning in interactive virtual environments called metaverses, particularly in Second Life.

Believing that being playful and experimenting are essential elements for the learning process, in formal and informal ways, and to the development of art and design projects we are doing an immersive experience of knowledge construction in the metaverse concerning e-learning and artistic languages for tridimensional worlds. One of developments by Isaura Seppi as avatar Janjii Rugani was the Project MADEinSAMPA.br (Fig. 2), in Second Life , this partnership with Centro Universitário SENAC-SP aims to create in a colaborative work with students a radio station to spread contemporary music from contemporary urban tribes, and a laboratory to produce machinimas and at last a project to develop History of Art classes offered openly to Second Life communities and general.

\section{Locative media as an Interface for Digital Cartography}

The new media, especially the locative one allows broad participation from all who live and interact in the city. Thus, the research project aims to organize and build a database from the material gathered during two years of the discipline Theory of Communication and Perception, which had the purpose of investigation and documentation of Sao Paulo through images, sounds and videos captured through the use of mobile technology. The ongoing project [13]-[17] considers the very individual perception from the common citizen levereged to a larger scale that ends up in a collaborative, democratic and inclusive map (Fig. 1). An ever-green reinterpretation of physical cities and the meaning of urban life through digital media and interface design. Therefore, in its second phase, the project aimed to build the information architecture and, subsequently, an online digital map. This project was presented at ISEA 2010 [18], at Designing the Hybrid City [19] and as part of Adaptation Festival and as invited lecturer at Raffles Design Institute.

E. VIDA: Virtual and Interactive Distance-learning on Anatomy

The VIDA project (Fig. 3) is a collaboration with the laboratories Interlab and LApIS of the Universidade de São Paulo and develops an augmented reality environment based on holographic-like interaction to be used in distance learning of anatomy. Instead of relying on a mouse and keyboard for interaction, the students manipulate three-dimensional anatomic models directly as if they were interactive holographic projections. 


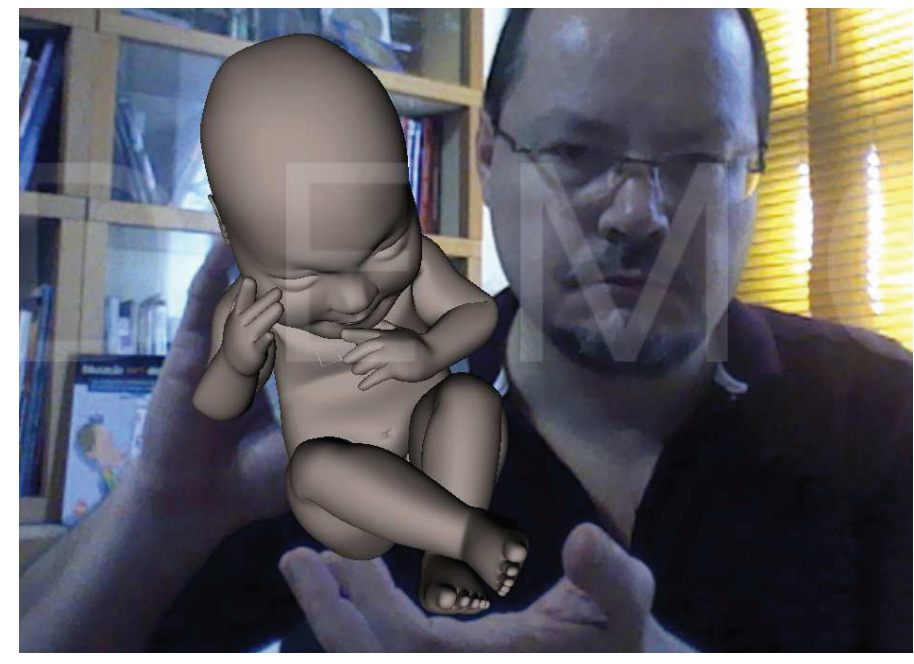

Fig. 3. Concept Image simulating the holographic interaction to be implemented in VIDA Project

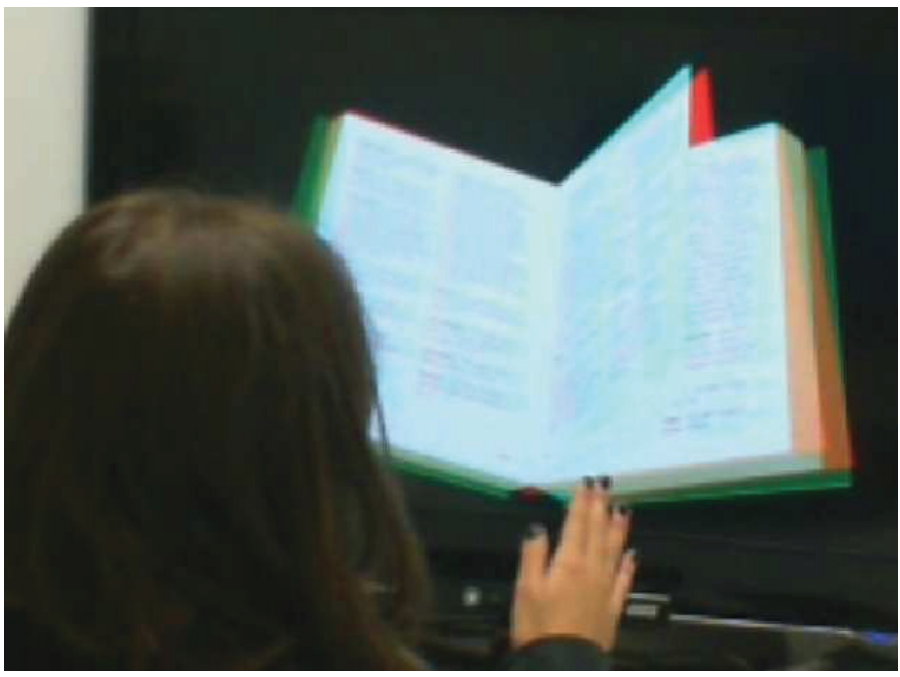

Fig. 4. user interacting with 3D Book (presented in anagliph format)

\section{F. 3D Book}

This project aims to develop a three-dimensional electronic book reader, whose interface is as close as possible to the experience of reading a physical book (Fig. 4). Its applications range from studying the impact of digitization on the reader's experience to a new form of virtual manipulation of rare books.

\section{CONCLUSION}

This paper presented the LPAI (Research Laboratory on Interactive Environments), which is linked to the Board of Graduate Studies and Research of the Centro Universitário Senac de São Paulo. This lab, created six years ago by researchers coming from research groups in communication, arts, design and computer science, previously existing in the institution, is dedicated to develop cutting-edge research related to interaction design in three-dimensional environments, be they virtual, real or mixed. More information about the laboratory, its members, its research and scientific production can be found in www.sp.senac.br/lpai .

\section{REFERENCES}

[1] C. E. S. Bueno, F. R. de Miranda, and R. Tori, "Projeto de design e implementação de uma ferramenta para visualização do interior de estruturas," in $P \& D$ design 2008 - Oitavo Congresso Brasileiro de Pesquisa e Desenvolvimento em Design, São Paulo, 2008.

[2] R. Tori, Da Realidade Virtual à Virtualidade Real. Belo Horizonte: Fonte, 2009, vol. 9, pp. 35-36.

[3] —_ Educação Sem Distância: As Tecnologias Interativas na Redução de Distâncias em Ensino e Aprendizagem. São Paulo: Editora Senac São Paulo, 2010, vol. 1, p. 256.

[4] _ _ "Desafios para o design de informação em ambientes de realidade aumentada," in Infodesign - Simpósio Brasileiro de Design da Informação Online, vol. 6, 2009, pp. 1-12.

[5] R. Tori, F. L. S. N. Marques, V. H. P. Gomes, and D. M. Tokunaga, "Vida: Atlas anatômico 3d interativo para treinamento a distância in:", in WIE 2009 - XV Workshop Sobre Informática na Escola - Anais do XXIX Congresso da Sociedade Brasileira de Computação. Porto Alegre: Sociedade Brasileira de Computação, 2009, pp. 1-10.

[6] R. Tori, F. L. S. N. Marques, R. Nakamura, J. Bernardes, C. G. Correa, and D. M. Tokunaga, "Design de interação para um atlas virtual de anatomia usando realidade aumentada e gestos," in Interaction South America 09 - Proceedings of Interaction South America 09. São Paulo: IXDA Brasil, 2009, pp. 1-12.

[7] F. R. de Miranda, R. Tori, C. E. S. Bueno, and L. P. Trias, "Ar Xray : Portable projector-based augmented exploration of buildings," in Proceedings of the X Symposium on Virtual and Augmented Reality, 2008.

[8] _ _ "Designing and implementing an spatial augmented reality x-ray," Revista de Informática Teórica e Aplicada, vol. 15, pp. 47-74, 2008.

[9] B. N. S. Vieira, C. Theodoro, L. P. Trias, F. R. de Miranda, and R. Tori, "Arhockey: Um jogo de realidade aumentada baseada em projetores," in DIGITAL PROCEEDINGS of the V Brazilian Symposium on Computer Games and Digital Entertainment. Porto Alegre: SBC, 2006.

[10] I. Seppi. Apresentação (no ambiente "second life") da performance dança dos bastões, de oskar schllemmer. in: Virtual worlds best pratices in education 2011. [Online]. Available: http://goo.gl/KDsfV

[11] —. Festa de confraternização (no ambiente "second life"). in: Jovaed - jornada virtual abed de educação à distância 2011. [Online]. Available: http://migre.me/5wT63

[12] I. Seppi and L. Agra. Apresentação (no mundo real) da performance dança dos bastões, de oskar schllemmer. Centro Universitário Senac. [Online]. Available: http://www.youtube.com/watch?v=YrM0rkLIl6g

[13] P. M. de Marchi and D. K. Hanns, "Cidade ubíqua e as novas espacialidades híbridas," in SILLAC 2010 Simpósio Ibero Americano Cidade e Cultura: novas espacialidades e territorialidades urbanas. São Carlos: SAP-EESC-USP, 2010, 2010.

[14] P. M. de Marchi, Urbanism \& Urbanization - International PhD Seminar. A new modernity - approaches, theories and designs, Venice, 2006, ch. City Boundaries in Transition. Urban Frontiers in Translation, pp. 201-208.

[15] — "Os desafios da arte comtemporânea," in III Simpósio Internacional de Arte Contemporânea do Paço das Artes, ser. Experiências/Campos/Intersecções/Articulações. Imprensa Oficial, 2009, pp. 126-129.

[16] — " "Interface entre cidade e tecnologia: a experiência do espaço tecnológico," urbe. Revista Brasileira de Gestão Urbana, vol. 3, pp. $27-39,2011$.

[17] F. Duarte and P. M. de Marchi, Fantasmagorias, vitrines, infiltrações: ensaio sobre as tecnologias e a cidade, ser. Mediações, tecnologia e espaço público: panorama crítico da arte em mídias móveis. Conrad Editora, 2009, vol. 1, pp. 35-44.

[18] P. M. de Marchi, "Re(cognition) mapping: redefining space, place and territory," in ISEA2010 RUHR 16th International Symposium on Electronic Art. Berlim: Revolver Publishing, 2010, pp. 512-513, 2010.

[19] _ " "City as interface of contemporary life," in Design the Hybrid City 2010 - Digital Proceedings, 2010. 